Trinity University

Digital Commons @ Trinity

Sociology \& Anthropology Faculty Research

Sociology and Anthropology Department

Fall 2017

\title{
Mourners in the Court: Victims in Death Penalty Trials, Through the Lens of Performance
}

Sarah Beth Kaufman

Trinity University, skaufman@trinity.edu

Follow this and additional works at: https://digitalcommons.trinity.edu/socanthro_faculty

Part of the Anthropology Commons, and the Sociology Commons

\section{Repository Citation}

Kaufman, S. B. (2017). Mourners in the court: Victims in death penalty trials, through the lens of performance. Law \& Social Inquiry, 42(4), 1155-1178. doi: 10.1111/Isi.12246

This Article is brought to you for free and open access by the Sociology and Anthropology Department at Digital Commons @ Trinity. It has been accepted for inclusion in Sociology \& Anthropology Faculty Research by an authorized administrator of Digital Commons @ Trinity. For more information, please contact jcostanz@trinity.edu. 
his belt. The attorney who elicits his testimony is patient, and after several false starts the man reads through the poem, memorializing his daughter for a room filled with family and strangers. As he stumbles down off the witness stand and returns to his seat behind the prosecutors' table, many of the audience members and jurors are crying.

This article examines the role of victims in death penalty sentencing. "Victim impact testimony" or (VIT), as exemplified above, has become routine in death penalty trials since 1991, when the United States Supreme Court handed down a controversial opinion allowing family members of the deceased to participate in the sentencing phase of the trial. According to the Court, VIT's inclusion is intended to give the jury a "quick glimpse" of the victim's life and the harm co-victims ${ }^{1}$ have suffered because of the victim's death, in order to support the state's case for execution (Payne v. Tennessee 1991). Legal scholars record this as a major shift in death penalty jurisprudence: before its inclusion in 1991, capital sentencing was generally understood to be limited to interrogating the character, deservingness, and dangerousness of the offender in order to determine whether he deserves death by execution or life in prison.

After observing the father reading his poem above and dozens of other victims' family members testifying in capital trials, I found VIT as a phenomenon best understood through the sociological concept of performance. With such a public show of sorrow in fact, there was no way to avoid thinking of it as first and foremost as a performance. Labeling it a social performance does not suggest that the emotions of the witnesses are in any way insincere. Instead the concept specifies that victim participation is necessarily a public (as opposed to private) enactment of a role that is social (as opposed to theatric) in that it involves real-world, socially structured relationships, produced both by and for groups of people with their own sets of norms and goals. Testimony involves a double consciousness on the part of the actors who participate. Whether they like it or not, co-victims must give their testimony in front of an audience. Testifying co-victims must simultaneously cope with emotions usually managed with in private, and a set of demands made by a public appearance. Institutionalizing such a social performance has an effect on the relationships of groups of courtroom actors, as well as the capital punishment institution generally, as will be discussed at length.

Most scholarship addressing victim participation in death penalty sentencing focuses on two questions, the first empirical and the second normative. First, does VIT affect sentence outcomes? Most commentators agree that victim impact testimony makes jurors more likely to vote for the death penalty, though to different degrees and for different reasons. Second, should VIT be a part of capital sentencing? Does participation at trial benefit co-victims? Does it fit within the moral and legal framework of capital sentencing?

In the passages that follow, I argue that these questions put the cart before the proverbial horse. Scholars should understand how VIT works before asking whether

1. "Co-victim" is sometimes used to describe surviving family members of homicide victims (Reed and Blackwell 2006). In this article, I will describe this group using "victim" and "co-victim" interchangeably, except when necessary to distinguish between the deceased victim and the surviving family members. 
it should be allowed. In this article I ask: How does victim participation in death penalty trials function in practice? And what do the practices tell us about the controversies surrounding victim participation in capital trials? Drawing on hundreds of hours of observations in fifteen capital trials in six states in the Northeast, Midwest, and Southern regions of the United States, I argue that this ethnographic study changes the way the institutionalization of VIT must be understood.

The article proceeds as follows. First, I provide a review of the role of victims in the US criminal justice system and the debate surrounding the United States Supreme Court's jurisprudence on victim participation in death penalty sentencing. Second, we enter the courtroom to see what victim participation in capital sentencing looks like in practice. Viewed through the lens of performance, I argue that covictims' social role in capital courtrooms is primarily that of a group of mourners, which gives them a socially sacred status. The discussion and conclusion emphasize that the institutionalization of VIT in capital trials does not "balance" the trial between offender and victim, but instead privileges victims because of their status as mourners. This privileging depends, however, on victims' performance of what scholars consider a "culturally successful" ritual (Alexander 2006).

\section{BACKGROUND}

\section{Death Is Different: The Strange World of Capital Murder Trials}

In the vast majority of criminal cases in the United States, an offender's sentence is decided without a trial. Most are instead negotiated between prosecution and defense as part of a plea agreement. For the approximately 10 percent of criminal cases that do go to trial, ${ }^{2}$ the judge, who may or may not hear evidence regarding the offender's social history, sentences the offender in large part according to state and federal guidelines. In order for a state to pursue the death penalty, however, the United States Supreme Court requires not only a trial, but also a sentencing decision made by a jury. ${ }^{3}$ If a defendant is found guilty of capital murder at a trial where the death penalty is a possible punishment, the jury reconvenes and hears testimony about the "character and propensities of the offender" (Woodson v. North Carolina 1976) from prosecution and defense witnesses. The jury then votes on whether the offender deserves death, as argued by the prosecution, or life in prison as argued by the defense.

This sort of second trial called a "penalty phase" is meant to provide jurors with information about the defendant's character so that the sentence is appropriate not only to the crime, but also to him as a person. ${ }^{4}$ While penalty phase trials are

2. This varies considerable according to circumstance, but is a fair simplified average (Galanter 2004).

3. There are occasional exceptions to this rule. For example, Ohio allows a defendant to be sentenced before a three-judge panel. There is also ongoing litigation in Delaware, Florida, and Alabama about whether judges should be allowed to override jury sentencing decisions. Hurst v. Florida (2016) most recently suggests judicial override might prove unconstitutional.

4. I use the masculine pronoun throughout because the vast majority of capital defendants are male. 
familiar in their form-opening and closing statements, defendant's council table and prosecution table, objections, bench conferences, and witnesses called to testify, for example-their content is less familiar to the US criminal justice system. For days, weeks, or months, and to differing degrees of effectiveness depending on the relative skill and effort of the participants, prosecution and defense use a variety of tactics that they think will persuade jurors to link the defendant's particular character to a lesser or greater punishment. Testimony might be taken from physicians, friends and family of the defendant, survivors of the victim, psychiatrists, psychologists, statisticians, religious figures, prison guards, and others, called by both prosecution and defense. The testimony of these witnesses can be used for opposite ends, depending on whether it is presented by the prosecution or the defense. A psychiatrist might explain a defendant's impairment at the time of the crime, or might suggest that the defendant will always be a danger to others. A clergyman might testify that the defendant has found God and is therefore salvageable or testify that the family of the victim has been deeply spiritually affected by their loved one's death. This article focuses on just one aspect of the capital penalty phase: victim participation. Victims have not always had a role in death penalty proceedings, but in the last forty years have become integrated into many aspects of the US criminal justice system.

\section{Victims in US Criminal Justice}

Victim participation in modern criminal legal proceedings re-emerged in the United States during the last four decades. Prior to that, one of the principal developments of the civil law system beginning in medieval England and later in the formation of the colonial United States was to separate crime victims from the state's condemnation of criminal activity. This was because of a concern with a neverending cycle of violence and revenge between offender and offended. The "impassionate" hand of the state was meant to punish offenders without a personal or emotional agenda and replace the cycle of violence. The separation of the victim's desires and the justice system's impartiality was a core component of the American criminal justice system (Acker and Mastrocinque 2006; Hostettler 2006, 2009; Langbein 2003).

During the latter half of the twentieth century, however, victims' exclusion from the criminal justice system drew protests from across the political spectrum. Individualized sentencing and rehabilitation programs for offenders, which had shaped modern US criminal justice, began to be criticized as ineffective. Advocates for reform of the criminal justice system generally split into two camps. The first lobbied for a renewed effort at rehabilitation. The second argued that the criminal justice system coddled offenders, and that victims were suffering. This second faction was successful at dominating public opinion and political agendas for several reasons. For one, it found support in several different areas along the political spectrum. Politically conservative groups were concerned that defendant's rights were being overemphasized. On an international stage, the specter of the Eichmann trials loomed large. Holocaust victims gave evidence of atrocities on a scale not 
previously imagined. Famously chronicled by Hannah Arendt (1963), the demonstration of the suffering of Holocaust victims impacted publics well beyond its courtroom. At the same time, the burgeoning second-wave women's rights movement publicized the plight of rape and sexual assault victims, who they described as doubly victimized: first by offenders and second by a state who treated them as complicit or even active participants in their assaults.

From these disparate concerns, a victims' rights coalition emerged as one of the new social movements of the late 1960s. In part because of this coalition, a more punitive model of criminal justice began to replace the rehabilitative. Offender rights were posed as antithetical to the interests of victims and victims were reintegrated into the criminal justice system (Barker 2007; Garland 2001; Weed 1995). ${ }^{5}$ The victims' rights movement was institutionalized during the decades that followed, through local and national legislation. During the 1980s and 90s, at least thirty-two state legislatures passed laws allowing varying degrees of victim participation in a variety of criminal procedures, most commonly allowing victims to write statements to the judges responsible for sentencing (Acker and Mastrocinque 2006).

Victim participation in death penalty trials holds a peculiar place in this history. Though death penalty trials are few compared to noncapital criminal proceedings, ${ }^{6}$ the use of victim impact testimony in capital trials has received a large amount of attention from the judiciary, scholars, and other interested parties. This is because the death penalty is so often a lightning rod in criminal justice debates, but also because of the increased protection afforded capital defendants in comparison to noncapital criminal defendants. According to modern US Supreme Court jurisprudence, the capital sentencing procedure is meant to focus on the character, dangerousness, and deservingness of the offender. Because of the "qualitative difference" between a life sentence and a death sentence, the Court stated that there should be a corresponding difference in the amount of attention given to the appropriateness of the punishment for offenders in capital cases (Woodson v. North Carolina 1976). The relatively extensive consideration of the defendant's character that has resulted requires more resources than noncapital sentencing. Capital defense teams spend months and years investigating their clients' social histories. Investigations may span generations, states, and even countries (Cooley 2004, 2005; Haney 2003, 2004, 2005; Sarat 1998; White 2006). Dozens of witnesses present days, weeks, and sometimes months of testimony about the character of the offender. This wide-ranging attention to capital offenders' social histories has been a large target for critics who argue that criminal defendants get too much attention generally. ${ }^{7}$

5. This is not to suggest that victims' rights are necessarily antithetical to defense rights. The alignment of the victims' rights movement with a conservative political agenda in the United States is the result of a group of historically specific factors. Barker (2007) points out that some victims' rights movements were in fact part of a more restorative model of justice in some jurisdictions in the United States and abroad.

6. Of the more than one million Americans convicted of felonies, fewer than one hundred death penalty trials take place each year.

7. On the other hand, advocates for capital defendants argue that many do not get adequate representation at all (see, for example, Bright 1994). 
In the late 1980s, the Supreme Court took up the question of whether the inclusion of victim testimony in capital sentencing might correct this perceived imbalance. Some states had incorporated victim testimony into capital trials, generally following the procedures established in noncapital criminal proceedings. There was one large difference, however. The deceased victims themselves could not testify, so friends and family were permitted to speak for them in some jurisdictions. These "co-victims," as they began to be called, were asked to submit written statements to jurors, while others were encouraged to testify in person. In other jurisdictions, co-victims were not allowed to participate at all. Facing pressure from both victims' advocates who wanted increased access to courts, and defense advocates who argued that victim testimony was inappropriate to the goals of capital sentencing, the United States Supreme Court addressed this varied use of victim testimony in 1987.

In Booth vs. Maryland (1987), the Court reviewed a capital trial in which two men were convicted of robbing and murdering an elderly couple in their home in the middle of the night. In a five-four opinion, the majority held that VIT was irrelevant to the character of the defendant and the circumstances of the crime and therefore inappropriate at sentencing. It also stated that the introduction of VIT created a risk that juries would impose the death penalty in an arbitrary and capricious manner in violation of the Eighth Amendment. Whether the victim was of good character and whether the family could effectively articulate that character should not have bearing on the defendant's sentence. The opinion concluded:

One can understand the grief and anger of the family caused by the brutal murders in this case, and there is no doubt that jurors generally are aware of these feelings. But the formal presentation of this information by the State can serve no other purpose than to inflame the jury and divert it from deciding the case on the relevant evidence concerning the crime and the defendant. (Booth v. Maryland 1987, 508-09)

Thus, victims were barred from presenting written or oral statements to the trial court about the harm done to them as a result of the murder. Two years later, the Court also banned the use of VIT to tell jurors about the good personal qualities of the victim (South Carolina v. Gathers 1989). But this defense victory was shortlived. As victims' rights were increasingly institutionalized in noncapital criminal proceedings across the country, the call for their inclusion in death penalty trials became louder. Four years after the Booth decision, in 1991, the Supreme Court again accepted a case that addressed the rights of victims during capital sentencing. This time, the makeup of the Court had changed. Appointments by Presidents Reagan and George H. W. Bush assured that the justices as a group were more conservative. By accepting the petition of Payne v. Tennessee (1991), the Court heard arguments about a death penalty trial that involved a brutal attack on a woman and two children. In another five-four opinion, the majority sided with victims' advocates. The majority opinion stated in no uncertain terms that co-victim testimony should be admitted during capital sentencing. The decision emphasized that VIT serves to give jurors more information about the "specific harm" caused by the 
defendant, a type of evidence "long considered by sentencing authorities." It went on to reason that VIT was appropriate to capital sentencing because it balanced the capital defendants' right to present character evidence at trial, explicitly overruling the Court's previous decision in Booth v. Maryland (1987) and weighing victims' rights against defense rights.

Consequently a new era in capital punishment sentencing was ushered in. Victim impact evidence was envisioned as balancing the testimony describing the defendant's character. In the twenty years since Payne was decided, nearly all states in the United States that authorize the death penalty have allowed the use of victim impact testimony at trial. Today, twenty-eight out of thirty states with the death penalty explicitly permit victims to give written or oral statements to the jury. The three that do not explicitly allow it (Montana, New Hampshire, and Wyoming) have ambiguous policies. ${ }^{8}$ Victim impact testimony featured at each of the fifteen trials I observed.

\section{The Scholarly Debate and the Role of Performance}

The dispute about the role of victims at capital trials continues despite the Supreme Court's rulings on the subject. These debates have developed along two general lines. The first line is empirical: scholars ask whether VIT affects jury outcomes. The second is normative, and inquires into the matter of whether VIT should be included in capital trials.

First, scholars have tried to assess VIT's impact on capital jury sentencing. Most agree that the inclusion of victim impact testimony makes capital jurors more likely to vote for the death penalty, though to different degrees and for different reasons. Bandes (1996) argues that the empathy aroused by VIT makes jurors generally unable to empathize with defendants. This line of argument has been qualified by empirical studies that suggest jurors differentiate between victims who are "worthy" or "unworthy" of sympathy (Sundby 2003). From interviews with thousands of capital jurors across the country, scholars have asserted that the victims' race (Haney 2004), gender (Williams, Demuth, and Holcomb 2007), and social status (Phillips 1997) have been found to influence jurors' abilities to empathize with victims (see also Eisenberg, Garvey, and Wells 2003; Johnson 2003, Logan 2000, 2006, Luginbuhl and Burkhead 1995). Experiments confirm that mock juries share the tendency to sentence more harshly if they can personally relate to victims (Myers and Arbuthnot 1999; Nadler and Rose 2002). In reviewing all of these studies, however, Karp and Warshaw (2006) find that VIT makes a slight but statistically insignificant difference to jurors' decisions, regardless of whether or not they empathize with the victims.

The second and more complex line of debate involves questions about whether victims should testify in capital trials. There are several frames through which this question is asked. Legal scholars argue whether VIT makes evidentiary sense. Some

8. According to the Death Penalty Information Center, at http://www.deathpenaltyinfo.org/legalissues-states-allow-victim-impact-statements 
stress that the harm done to the victim is factored into the charge of capital homicide and that co-victim participation of has no place in sentencing. Others-like the ruling jurisprudence-reason that the harm done to victims should be used to "balance" the character testimony presented to mitigate the defendant's guilt. ${ }^{9}$

Two major lines of inquiry dominate debates around the moral questions. First, there is argumentation about the benefit VIT can bring to those mourning the victims. Some argue that the ability to testify provides co-victims with much needed closure, whereas others have found that involvement in capital trials can overly burden or retraumatize them. ${ }^{10}$ Acker and Karp's (2006) first-person accounts from victims in capital trials provide the best evidence of victims' varied experiences in capital trials. From these accounts, it is fair to say that participation in courtroom testimony helps some victims and retraumatizes others, and that there are factors that effect participation that may be as important as the testimony itself. Goodrum (2013), for example, demonstrates that the relationship between the prosecutor and the co-victims is key in determining co-victims' feelings about capital trials.

Others evaluate VIT as part of a resurgence of emotion in contemporary Western law (Bandes 1996; Garvey 2000; Sarat 2001; Arrigo and Williams 2003). The classical framework of the Western legal institution as a rational arena, free of emotion, has been questioned for some decades now. Bandes (1999), Garland (2001), Karstedt (2002), and Pratt (2000), among others, have pointed out that many aspects of the contemporary American legal system integrate emotion into a realm supposedly reserved for reason and rationality alone. But Bandes (2009) argues that capital law has failed to grapple with the role of emotion. This failure means legal decision makers cannot accurately predict VIT's effects.

Recognizing VIT as emotionally complex brings us closer to a fuller understanding of how victim participation works in capital trials, But "emotional" can mean any number of things. To understand how the emotional nature of VIT impacts capital trials, it must be studied in practice, in the context of the capital courtroom. Bandes $(1999,2009)$ argues for a "contextualization" of victim impact testimony in its institutional and psychosocial context. For this, a theory of performativity and ritual is needed.

As Austin (1975) first described, speech acts must be recognized as performative. Further, speech acts do not exist without bodies and relationships. Goffman (1959, 1961) conceptualizes social worlds as composed of a series of dramaturgical performances. Such performances are not entertainment-they are reflexive processes through which humans recognize themselves and others. The actors in capital trials are not only expressing emotion, they are performing for one another-witness for jury, judge for audience, and audience members for one another, for example. These performances are not insincere. Rather the Goffmanian concept of performance emphasizes actors' desire to be understood, even within the constraints of the legal setting.

9. For a detailed discussion of the evidentiary role of VIT, see Engle (2000) or Logan (1999, 2000).

10. A study examining mock jurors' responses to victim impact testimony by Nadler and Rose (2002) influenced a line of subsequent studies on this point. 
Alexander (2006) develops a framework for analyzing this emotion-laden communicative work. Following Durkheim ([1915] 1965), he emphasizes how performances can build community relationships through ritual in public settings. Alexander (2006) draws on Goffman (1959, 1961) and Schechner (1993), among others, to develop the concept of the contemporary "social performance," which is a secular communicative act that has the capacity to build solidarity between actors and their audiences. When effective, such social performances bring actors and their audiences together in a ritual-like affirmation of a cultural notion held dear. If not effective, social performances are witnessed as inauthentic, and solidarity is not achieved. As I will show, VIT institutionalizes just such social performances. VIT is a rare act in the criminal justice system where bureaucracy and discipline often supplant any potential for ritual solidarity.

According to the Supreme Court, VIT is intended to serve two purposes: to provide information about the character of the deceased victim, and to describe the harm that the crime has done. In practice, it does much more. As I will show, much of the audience's focus throughout sentencing turns on the emotions of the surviving victims and their supporters who are present in the courtroom. This is not surprising if we conceptualize them not as legal actors, but as mourners who have lost loved ones. By conceptualizing VIT as a social performance of mourning, I show how victims hold the potential to structure the relationships in capital courtrooms in a way that other groups do not.

\section{RESEARCH METHODS}

There is a strange lack of data about capital trials in the United States. The United States Department of Justice Bureau of Statistics collects extensive data on homicides, arrests, and prison sentences for convicted murderers; advocacy organizations such as the Death Penalty Information Center and Human Rights Watch have extensive information on the people on death row and state execution processes; and the National Center for State Courts records all types of criminal sentences, but no national organization tracks when or where death penalty trials are happening around the country, nor their results. A few states and localities have begun to require such information, but there is no national compendium of information about death penalty trials in the United States. ${ }^{11}$ Without this information we cannot make systematic claims about death penalty sentencing trials, and trial practices remain disconnected from the larger role of capital punishment.

The present study remedies this in part by observing selected capital sentencing trials in order to begin to identify common practices. Unlike previous studies that focus on trials in one state or another, I chose to attempt to compile data that reaches toward national representation. In order to observe as nationally

11. I confirmed this with experts in the field, including representatives from the Death Penalty Information Center and the Department of Justice. 
representative a group of trials as possible, I used a systematic sample. ${ }^{12}$ In lieu of any definitive population from which to sample, I used newspaper accounts of American capital trials compiled by the American Judicature Society. ${ }^{13}$ These provided a sketch of where capital trials take place around the country. I combined these with previous findings suggesting that trial outcomes vary by county demographic differential (Lofquist 2001; Gershowitz 2010), level of funding available for indigent defense (Tabak 1994; Bright 1994, 1995; Vick 1995; White 2006; Redick, MacLean, and Truett 2008), and race of victim and defendant (Baldus, Pulaski, and Woodworth 1990; Oggletree 2002; Baldus and Woodworth 2003; Fleury-Steiner 2004; Allen and Clubb 2008). I then chose selectively state and federal death penalty sentencing trials for tracking and observation, with the goal of maximum variation on these characteristics.

During 2007, 2008, and 2009, I observed three federal and twelve state trials in Pennsylvania (2), New York (2 federal), Virginia (1 Federal), Louisiana (3), Texas (6), and Illinois (1). Trials ranged from several days to several weeks. In the tradition of the multi-sited ethnography (Burawoy 2000; Falzon 2009), I treated each trial as a site in a collective "social world" (Strauss 1977), bound not by space but by institutional logic. Each trial was of course unique in its arrangement of actors, locations, and circumstances, yet undeniably interconnected through its mutual dependence on a shared group of institutions and institutional actors. In every trial, the workings of the criminal law in the United States set the scene for much of the action; in every trial, capital prosecutors, defense attorneys, and expert witnesses were networked, to greater or lesser extent, to other others in their fields. Trial actors also shared sets of cultural norms, as I will discuss. In total I observed more than eight hundred hours in fifteen courtrooms. I also interviewed trial actors, including prosecutors and their staff, defense attorneys and mitigation investigators, victims' supporters, courtroom staff, defendants' family members, expert witnesses, and members of the media. ${ }^{14}$

Following the "reflexive turn" of ethnographers in sociology and anthropology during the 1980s, I make use of not only my interviewees' observations and emotions in my analysis, but also my own. Death penalty trials are indeed emotional proceedings; pretending to be a completely "detached" observer would be ingenuous. Instead I follow others who make use of their emotional reactions to fieldwork by leveraging them as data when illuminating. ${ }^{15}$

12. The technique of "systematic" rather than random sampling was done in accordance with the National Science Foundation's "Qualitative Research Design and Methods: Strengths, and Shared and Unique Standards," found at http://www.nsf.gov/sbe/ses/soc/ISSQR_workshop_rpt.pdf. More information on my method is available.

13. Two hundred and thirty-three news reports from 2005, compiled from the American Judicature Society Capital Case Data Project, available at http://www.ajs.org/jc/death//jc_death.asp.

14. The vast majority of these interviews were informal, conducted in the hallways, bathrooms, and cafeterias around the courtrooms I observed. I also conducted fifteen formal interviews with capital defense attorneys, which I also draw on. I was unable to interview the defendants themselves, jury members, and judges, all of whom were barred from talking about the cases, as they were ongoing.

15. In this I draw on the tradition of ethnographer and feminist researchers (e.g., Smith 1974; Clifford and Marcus 1986; Luhrmann 1989; Ulysse 2007) who have an epistemological commitment to recognizing one's own subjectivity in the field. Though a researcher is not a member of the field of study per se, his or her reactions to the field should be explored as data. For some recent discussion of the role that emotions should play in social scientific research, see Hubbard, Backett-Milburn, and Kemmer (2001), Hume and Mulcock (2004), and Dickson-Swift et al. (2009). 
To compare my observations with the information available to appellate courts, I also obtained trial transcripts whenever possible. My ability to do so depended on the goodwill of the court reporters in each trial; transcripts are not generally made available to the public until the "official" record is filed, often months after trials conclude, and can be prohibitively expensive. I was lucky to meet five court reporters who shared their electronic copies with me soon after I completed my observations. I used these to compare the official court record with my ethnographic notes.

The data and analyses culled from this research are the first ethnographic data compiled from multiple capital trials across the country. They are preliminary in this sense, and are meant to open doors to further exploration.

\section{MOURNERS IN THE COURT: SPACE, ACTION, AND RELATIONSHIP}

Appellate courts rely on trial transcripts to issue legal rulings. Yet transcription systematically erases information that I argue should be used to form a more honest evaluation of victim participation in capital trials. For one, the highly emotional content of victim testimony is drastically tamped down through the process of legal transcription. VIT is rendered almost lifeless when separated from the tone, facial expressions, and body language of grieving witnesses, as well as the audience members' and jurors' responses. Second, transcription captures co-victims' on the witness stand, but their presence in the courtroom during the trial goes well beyond the witness stand. Together these factors produce a transcript that bears little resemblance to the role of victims in the courtroom.

I begin by describing how VIT reads after it has been transcribed, drawing on the five transcripts I acquired. I then detail how victim participation in death penalty sentencing actually works from an observational perspective.

In the five transcripts I obtained, the prosecutor's case for death began by calling between two and six co-victims to testify about the victim's character and the impact of their loss. The examples below capture the essence of this testimony. By and large, VIT features three common narratives which are shaped with details specific to the victim. First, there is a positive, even "angelic" portrait of the character of the victim. Here the best friend of a murdered university student described the victim:

He was an angel. Really. I know that people say that about lots of people, but he was really the nicest person I knew. He would do anything for me. And he loved his nephews. They were always talking about him.

Second, a loved one describes the last time he or she heard from the victims. In the below case, the mother of a victim at another trial described the last time she spoke to her daughter on the phone: 
She called me a couple of days before she got killed, she said, Mommythe phone rang, must have been about 11:30— that was unusual. I started not to answer it, but when I heard her voice on the answering machine, Mommy, I pick up the phone. She says, I just called you to tell you I love you. ... Next thing I knew, the detectives was at the door and they was telling me she was shot.

Finally, co-victims testify about the effect of the loss on their family. Here another mother testified about how her family's life was affected by the murder of her oldest son:

My family is just crushed. My younger son has said none of us look the same, none of us sound the same. I know it's only been just a little over a year, but we're just not the same family. We'll recover. We know he's with the Lord and we're going to see him. It's not that. It's just that for now, it's a very hard recovery. It was so sudden and tragic. He had just recovered from cancer. Spent a year fighting cancer. And after all the struggles he had, and he just was about to realize some of the benefits of all that he had worked for and then he-it was all over.

These are typical of VIT, though they are considerably abridged; the above paragraphs are embedded in forty-, fifty-, and seventy-odd pages of transcripted victim impact testimony, respectively.

Prosecutors then typically draw on these narratives from VIT in their closing arguments at sentencing. They commonly ask jurors to take into account the suffering that the defendant has caused the friends and family of the victim. In the case of the murdered daughter above, the prosecutor told jurors in closing:

Focus on the unspeakable hell that he [the defendant] put those families through ... because of that man, because he decided to go hunting on the streets of this city, those people's families have nothing left to hug but memories, and we're asking you to remember them.

Thus, from the trial transcripts, readers are most likely to get a sense that the victim of the murder was a good or even exceptional person, that the family and friends of the victim have suffered greatly, and that the jury should consider these surviving co-victims' pain in their decision about the defendant's sentence. ${ }^{16}$

\section{VIT in the Courtroom}

Legal transcription captures little, however, about the totality of co-victim participation in death penalty sentencing. Co-victims and victims' supporters are

16. Logan $(2000,2006)$ writes that victims are also likely to be asked by prosecutors to give their opinion on the stand that the offender should be sentenced to death. I did not record this in my fieldnotes, though looking back, I do believe it may have occurred in one or two cases. 
involved in multiple relationships in the courtroom, visible to anyone in attendance. They testify, but they do much more. ${ }^{17}$

First, I observed testifying co-victims relate with lawyers, audience members, and jurors in ways that were not recorded in transcripts. To the best of my memory, in all but one trial I observed, co-victim witnesses cried on the stand. In several, they sobbed and had to take breaks to compose themselves. Tissues were routinely handed to them, as were glasses of water. Their pain was not just described but reenacted in front of jurors, judge, and audience members. These performances were met with almost universal empathy from the people in the courtroom, which were not transcribed. Audience members cried, passed tissues, held hands, and comforted one another. I saw jurors weep, and I was moved to tears on more than one occasion. Though I have never experienced a violent attack on a loved one, memories of lost loves and lost opportunities flooded me. In the case in which the father testified, recounted in this article's opening, a defense attorney even called attention to his own crying during victim testimony. After the victim's father read the poem, the lead defense attorney stood up and asked the judge for a mistrial. He said that "people in the courtroom, most notably at defense table, most notably myself," were visibly moved by the testimony and the jurors might have been affected by seeing them cry. He said he, for one, thought his crying might have been de facto ineffectiveness of counsel. In short, VIT testimony was often heart-wrenching for everyone in the courtroom, not only victims' supporters.

Victim participation in capital trials also goes beyond giving formal testimony. Off the stand, co-victims' role in the trial is entirely untranscribed, but is a key factor in structuring the relationships in the courtroom. All action in the courtroom is organized by the material and symbolic demarcation of the "front stage," where the action takes place, and the "audience."18 Front stage actors include the judge, sitting in the front and center of the courtroom on a raised bench with court reporter and clerk desks in front; defense and prosecution teams, seated at identical large rectangular tables on either side of the judge; and a jury, usually seated in a cordoned off box of some sort. The verbal exchanges of trial actors that are captured by transcript take place only in this front stage, except in the unusual event that front stage actors bring attention elsewhere. Though the audience is an active force in the courtroom, it is absent from the action captured by the court reporters. Victim participation is therefore only considered part of the proceedings when a covictim comes from the audience or backstage and enters the front stage to sit in a witness seat.

But in my observations, victims' supporters in capital trial courtrooms were as dominant a presence as the "major" players. I regularly encountered and made note of action driven by the judge, attorneys, jury members, defendant, or courtroom

17. It is worth mentioning here that one relationship that was surprisingly absent from the majority of victim interactions was that between the co-victims and the defendant himself. From fictional accounts of criminal trials, one might expect a confrontation between these two parties. And though I did see two defendants read statements of remorse, at times addressing the victims' family directly, I did not witness any dramatic interaction between these two groups beyond this. For the most part, expressions of anger and sorrow were mediated through other relationships.

18. I employ Goffman's (1959) terms here to demonstrate the dramaturgical nature of the courtroom. 
staff. I also found myself just as likely to be drawn to the audience members, composed mainly of the victim's friends and families. ${ }^{19}$ Audience members were normally seated on wooden benches arranged in divided rows like church pews, and were themselves divided. In some courtrooms this was formally marked, whether by ragged pieces of paper taped up on the ends of rows of benches, or professionally produced signs standing at the courtroom entrance. The signs indicated seats reserved for "media" and "family," meaning victims' family, and less often sections for lawyers' staffs and defendants' families. Even in courtrooms without formally marked divisions, audience members divided themselves in similar ways. The victims' family and friends sat in the pews nearest the prosecutor; the media, if any, gathered in a less prominent area toward the back; and the rows closest to the defendant held defense supporters, if any were present. In all of the trials I observed save for one, victims' supporters greatly outnumbered defense supporters.

This setup was not incidental. The division of the sides structured an unspoken dynamic in the courtroom that was palpable to spectators who entered. Visitors who were alien to the courtroom revealed the strength of this invisible orchestration. Upon entering, unfamiliar visitors were likely to sit down in the first available row. After sitting for a few moments, they would glance around and get a feel for the room. In several courtrooms, visitors became visibly discomforted when they discovered themselves to have unwittingly taken a wrong position in the space. One man found himself sitting in the defense section when he meant to support the prosecution. He caught the eye of the victim's advocate-a professional from the prosecutor's office-and quickly realized that she was keeping charge of the victim's family. He fidgeted, waiting to reposition himself during a break, and then finally snuck over to the appropriate row, nodding at the advocate like a child eager to be acknowledged for his good behavior.

As an observer, I also experienced a difference in attitude toward me depending on where I sat in the courtroom. Though I would always introduce myself, I was treated as a "graduate student writing about murder trials," differently depending on where I was seated in the courtroom. In one trial, I sat with the defense supporters who were mostly young legal clerks. Though I shared a courtroom, lobby, elevators, and cafeteria with the co-victims and victims' advocate for several weeks, no victims or their supporters ever made eye contact with me. They acknowledged my presence only with hostility. When we came upon one another, they averted their eyes, changed topics of conversation, fell silent, or walked away. It never felt appropriate to introduce myself, and I remained vigilantly formal. In other trials, when I sat with victims' supporters, I was able to have conversations with family members and friends of the victim. ${ }^{20}$ One conversation made especially clear to me how much anger simmered under the surface between the two groups. During an afternoon break I found myself washing my hands next to the wife of the victim in

19. Though most capital proceedings are open to the public, I was surprised how sparsely they were generally populated. Though a few of the trials I observed garnered large attention from surrounding communities and media, the majority were attended by victims' supporters, and some days not at all.

20. This was easier when victims' supporters were in smaller groups of two or three and not accompanied by a representative from the district attorney's office. The implications of this will be discussed in this article's conclusion. 
the bathroom nearest the courtroom. We could not help but interact as we both reached for the paper towel dispenser, and I said, "I'm so sorry for your loss. ... I can't understand what it must be like going through this." Having wet her face from the faucet and in the process of mopping her eyes with a paper towel, she shook her head violently and replied in a voice that felt too loud for the space: "What I don't understand is how anybody could represent that slimeball!" I was not surprised by this burst of anger, as I could see it smoldering in her gestures and expressions in the courtroom as I sat nearby. But I was surprised that her anger was directed at the defense team and not the defendant himself.

Victim and defense supporters were not only separated spatially in the courtrooms. Groups also formed their own internal patterns of behavior. In fourteen out of fifteen courtrooms, victims' supporters far outnumbered the defense supporters. Victims' supporters also tended to look more organized and better prepared for their appearances. Here are excerpts from my notes on the morning the penalty phase began. Victim and defense supporters filled the courtroom.

The scene in the courtroom is more chaotic and noisy today. Attorneys and staff are searching through document boxes and the audience seems more crowded and talkative than they did during the guilt phase of trial. Then the judge enters suddenly and a bailiff calls the court to order. Everyone quiets down, stands up, and sits back down when the judge gestures. There is a short pause while attorneys and courtroom staff finish shuffling their papers. The judge looks like he is polishing his glasses. I hear the courtroom door open behind me, and turn around to see a slight teenage boy wearing a huge red $\mathrm{T}$-shirt down to his knees and black shorts almost touching his ankles framed in the doorway. He pauses for a moment, surveying the scene with a scowl, and then walks a slow, deliberate lope down the center aisle of the audience. He doesn't stop until he comes almost to the knee-wall separating the audience from the front stage. He turns to face the packed front row and then waits, arms folded, standing next to a sign marked "Defendant's Family." The women at the end of the row gather their bags and jackets into their laps to make room for him. They squeeze together, and he sits down. I then notice that a skinny and tense-jawed young woman carrying a sleeping infant is behind him. She is blatantly glaring at the judge and jury. She looks like she wants to kill them, and I assume she is a family member or friend of the defendant who is angry at the conviction. The people in the row squeeze together more to make room for her. The courtroom door slams shut. Many eyes follow these actions.

On the other side of the courtroom, already seated in a section of the audience marked "Victim's Family," is a group of several dozen professionally dressed people. A few have been in the audience for the whole trial, but most are new. Also new today is their attire: they are more formally dressed and each has a pin about six inches in diameter fastened to the left side of his or her shirt. On every pin is the face of a smiling young man: the victim. Collectively this group appears solemn; anticipatory but also nervous. The prosecutor offers his opening statement and calls his first witnessone of many co-victims to testify. As the morning progresses, defense 
supporters are agitated and fidgety. Groups of two or three of them walk in and out of the courtroom with some frequency, banging the door each time. Victim supporters alternately laugh, cry, and nod along with the victim impact testimony. They put their arms around each other and enter and exit the courtroom en masse, only during breaks. By mid-morning, several jurors look to be crying as victims' family members continue to testify. At some point the prosecutor puts a box of tissues on the kneewall in front of the jury, and the victim supporters are passing around tissues of their own. Just before noon, as his last piece of evidence, the prosecutor plays a recording of the victim's last call to 911. Upon hearing the victim's voice, two women sitting in the "Victim's Family" section begin sobbing loudly. Jury members' heads jerk toward them, looking wide-eyed like deer caught in headlights. A few women in the defense family section jump up. The judge instructs the jury to disregard the sobs and to exit quickly for lunch as the state rests its case. (Extract from fieldnotes)

Several things are evident in the scene above. First, audience dynamics play a central part in the courtroom action. Second, defense supporters and victim supporters formed separate and contrasting groups, prompting a comparison between them. The two groups in this trial played different roles in the audience. The defendant's family and friends gave off the impression of being angry with and defiant toward the court and the jury. While some of the older women who sat in the front rows dressed and acted respectfully toward the court, the younger defense supporters made their angry feelings apparent. In contrast, the victim's family and friends were organized and established, almost at home in their individual and group expressions of anguish. These dynamics were noticeable to anyone in the courtroom, but did not make it into the legal record. The judge, jury, and members of the courtroom staff all reacted to the two groups, but because their actions were not preserved on the record they subsequently become institutionally invisible, unavailable for review by academic researchers or appellate courts.

In this way, VIT organizes a show of compassion for co-victims. Looks of empathy, glasses of water, and pats on the arm were plentiful and understandable, but significant given their context. Together these gestures suggest trial court -as institutions -grant legitimacy to the victims' position. But in some trials, the institutional validation went a step further.

In five out of the fifteen cases I witnessed, a victims' support person employed by prosecution's office was present at trial. In all cases female, these women functioned not only to comfort and organize victims' supporters, but also to negotiate the group's position in relationship to the judge. Victims' advocates moved through the courtrooms in ways that others did not. The barrier between audience and front stage, normally a knee or waist-high wall as I have described, is protected and breached to varying degrees. It marks the division between the legal actors and the non-legal public. In larger courtrooms or where there was a lot of publicity surrounding a particular case, this barrier is guarded by bailiffs or uniformed sheriffs. Court reporters, judge's clerks, bailiffs, and attorneys have on-going permission to enter and exit the front stage, whereas witnesses are admitted only when they are called to testify. All others stay out. Those that are admitted appear to have 
privileges granted by the court, marked in space in a way that the audience and the jury can observe. In three cases victims' assistants were also privileged in this way, free to walk into and out of the front stage area like one of the clerks or judge's clerks. This reinforced the co-victims' legitimate position in the courtroom in a way I never saw legitimized for the defense.

A woman with the efficient air of a schoolmarm accompanies members of the victim's family at all times, sitting with them in the audience in the courtroom, and talking with them when court is not in session. During the state's case for death, she holds a witness list and walks between the prosecution table and the audience. She silently and verbally organizes family members and their supporters, gesturing for them to sit, and whispering quietly when something is confusing. The judge sees her entering the front stage area and does not scold her as he did when an unauthorized witness stepped in before. The victims' assistant is not reprimanded for talking while the court is in session, or for walking in and out of the courtroom at will. There is no equivalent on the defense's side. (Extract from fieldnotes)

The presence of the victim's assistant elevates the status of co-victims and their supporters in the courtroom. Observers see not only victims' assistants' gestures and intentions, but also that they are condoned by the trial judge. This gives the victims' families an institutionally supported role in the proceedings, regardless of whether they testify. I never saw defense advocates given these same privileges. Sometimes defense attorneys or mitigation specialists sat with defendants' families. They too would explain what was happening, and organize those who were called to testify. Rather than receive support from the judge or court staff, however, I only saw these figures reprimanded for talking during session.

Instead, courtroom actors routinely took their emotional cues from the victims' supporters. This was made especially evident in two trials where audio/video recordings were used to describe, or as one prosecutor put it, "memorialize" the victim as part of the victim impact testimony. The juries watched as montages of images of the victim in various settings played on big screens. One featured the victim singing in church, at a birthday party, and finally at home with his children. Music played over the top, and jurors were riveted to the images on the screen. As sniffles began to be audible in the audience, the attention in the courtroom became divided. Jurors' eyes moved back and forth between the video and the victim's supporters in the courtroom as they wiped their eyes, whispered to one another, and pressed close together in their pews. When the video concluded, all eyes turned to them asking for cues as to how they should react from the victims' supporters rather than from the judge's instructions.

Out of the fifteen trials I observed, only three lacked the dominant presence of victims and their supporters in the courtroom. In one trial, there were no victim supporters in attendance and no testimony from victims. In two other trials covictims did testify, but off the stand they appeared disorganized and disrespectful of the courts rules, in a manner similar to the defense supporters in the scene I 
described above. In these cases, the victims' sorrow was less dominating a presence in the courtroom, and the victim impact testimony was not as moving. Co-victims were asked simply, "how do you feel about your loved one's death?" and answers tended to be general and vague.

\section{DISCUSSION AND CONCLUSION}

Victim participation in practice involves a greater number of more complex relationships than is obvious when trial actions are transcribed. In the vast majority of the trials I observed, it shapes interactions among audience members, jurors, defense supporters, and nontestifying victim supporters. This has consequences not acknowledged in the Supreme Court's decisions or adequately addressed by academic discussion of victim impact testimony. ${ }^{21}$ This section details these consequences. I leave it to others to demonstrate that the Supreme Court, by allowing co-victims to become testifying witnesses, may have altered jury verdicts or given victims more satisfaction with capital proceedings. My observations demonstrate that its institutionalization accomplishes other things. By making the performance of sorrow a legal aspect of sentencing trials rather than just part of the audience dynamic, the role of victims becomes doubly significant. If victim support is strong and a "successful" social performance of mourning is achieved, audience members, jurors, judges, and courtroom staff become party to the social rite of mourning. This both steps up the antagonism between groups of victim and defense supporters, and rewards those victims who have the resources to perform such a successful ritual.

\section{The "Balancing" Argument}

The Payne Court reasoned that VIT "balances" mitigation evidence. The Court notes that the defendant's girlfriend in Payne was allowed to introduce evidence that the defendant was a caring father and partner, and that they met in church. It reasons that the uniqueness of the victim should be introduced in a similar way; that the "parade" of witnesses praising the defendant should be balanced. The Court's argument that victims should be moved back into criminal proceedings makes sense, given the cultural and political atmosphere of late twentieth-century America. As Garland (2001) and Simon (2007) among others point out, courts, legislatures, law enforcement agencies, and other publics were especially concerned with the perceived plight of the crime victim during the last decades of the twentieth century. The crime victim became the idealized subject of the law, central to a host of legal and extralegal forums during the 1970s and beyond. ${ }^{22}$

21. However, there is a body of literature that looks at the ways that victims' interactions with the criminal justice system are traumatic in themselves. Reed and Blackwell (2006) provide a review of recent literature, and Part I of Acker and Karp (2006) provides first-person accounts from capital co-victims. I have not found any research, however, that looks specifically at the relationships between victims and other trial actors during capital sentencing.

22. See Simon (2007), Chapter 3, for more on the victim's idealized subjectivity. 
But my observations show that the institutionalization of victim impact testimony does more than honor the victims. In almost all of the trials I observed, the focus is not so much on the character of the deceased, but on the emotions of the surviving family members and their supporters. Though the deceased victim's character is praised during portions of victim impact testimonies, victim supporters who sit in court receive more attention. In the most emotionally powerful trials, the victim is memorialized in a way that provides catharsis for friends and family. Their grief, in turn, becomes part of, and in some cases the dominant tone in the courtroom. The mourners, rather than the judge, lawyers, or defendant, provide emotional cues that command much of the courtroom's focus.

This attention paid to victims' supporters is not surprising given the cultural role of mourning. Expressing sorrow in reaction to a loved one's death is an old and universal ritual, and mourners are given a special status and dispensation across cultures. From the Australian Aboriginal tribes (Durkheim [1915] 1965), to mothers mourning their dead infants in twentieth-century Brazil (Scheper-Hughes 1992), mourners do more than express spontaneous emotion. They hold a powerful potential to organize community sentiments. As Durkheim would have it, the ritual coming together of people who are mourning and the community members who support them is a necessary step in affirming the importance of being a part of that society:

When someone dies, the family group to which he belongs feels itself lessened and, to react against this loss, it assembles. ... Not only do the relatives, who are affected the most directly, bring their own personal sorrow to the assembly, but the society exercises a moral pressure over its members, to put their sentiments in harmony with the situation. ... A family which allows one of its members to die without being wept for shows by that very fact that it lacks moral unity and cohesion: it abdicates; it renounces its existence. (Durkheim [1915] 1965, 445-46).

Thus victim's family members, their supporters, and even those who do not know the family but who witness their mourning, might be said to be under a moral and social obligation to support the rituals. Whether at a funeral or at a capital sentencing hearing, witnesses to grief are socially compelled to show empathy with the mourners. Close family members as well as distant community associates who do not display empathy are judged as cold or inadequate.

As such, institutionally sanctioned acts of public mourning during death penalty trials have the potential to culturally compel spectators to support victim's family members. When a successful performance of mourning is coupled with a prosecutor's argument to honor the victim's family by voting for a death sentence, the appeal for execution is equated with an entreaty for strong community. In Alexander's (2006) terms, the successful social performance unites the audience with the victim. This has two consequences.

First, the potential for solidarity building of co-victim testimony must be considered in comparison to mitigation testimony, as the Supreme Court suggests. While VIT makes victims worthy of empathy, mitigation testimony can work the opposite way. Haney $(2004,2005)$ and others have catalogued how defense 
mitigation can be unfamiliar and even alienating to jurors and audience members. Their narratives often involve family dysfunction, mental illness, physical and sexual abuse, all of which which can be shameful and stigmatizing. While defense lawyers might aim to promote solidarity by presenting such evidence about the defendant, they face much greater cultural barriers than prosecuting attorneys. The Supreme Court's "balancing" metaphor, from this perspective, makes little sense.

Second, we must consider those acts of public mourning that are less "successful" in Alexander's (2006) terms. In Booth vs. Maryland (1987), the Court is rightfully concerned that institutionalizing VIT creates a risk that some victims would receive more sympathy than others. It asks whether victims' ability to articulate their feelings should have bearing on the defendant's sentence (Booth v. Maryland 1987, 505). My observations suggest that the institutionalization of VIT has indeed meant that victims receive more or less sympathy. I would argue that this has little to do with how worthy the victim may have actually been-or more to the point-how much the defendant deserves death but more to do with the success of the mourning ritual. Reframed through the lens of performance, we might ask: What makes for a successful social performance of mourning in contemporary society? Simon (2007) suggests that crime victims have been imagined as the idealized subjects of the law in contemporary American criminal justice. When creating judicial or legislative benefits for survivors of crime, victims are imagined to be white, suburban homeowners. I would argue that victims' supporters in capital courtrooms also labor under that imaginary. Grieving the loss of a loved one takes all kinds of forms: from celebration to seclusion to public parading (Rosenblatt, Walsh, and Jackson 1976; Hockney 2001). The victims I observed as most successful in compelling the emotions of others, however, conform to a middle-class Western norm of public mourning. They display minimum anger, they cry in a controlled manner, and they display respect for the proceedings. Further study would need to look at how victims are received who do not fit this mold. How might an overly different form of mourning be received? How do race and class position effect the success of social performance of mourning?

Further, my observations suggest that the institutionalization of VIT pits defense against victim supporters. There was little outright conflict, but there was no denying the presence of a kind of revulsion, best demonstrated by the victim's wife I encountered in the bathroom. Of what use is this anger, we must ask. As others have argued, emotion is inevitable in the context of capital sentencing and should be dealt with head-on rather than pretending it does not exist. The call for an "emotionally intelligent" justice is at the core of a call for a re-envisioned criminal justice system (Sherman 2003). In noncapital cases, emphasizing victim and defense supporters' "shared suffering, common sources of pain, and systematic causes of victimization" allows participants to avoid the struggle to decide who is more oppressed in the criminal justice system, or who deserves more or better rights (Barker 2007). These shared emotions could also be accentuated in the capital context. Families of victims and defendants in capital cases have both experienced tremendous loss. How would an emphasis on shared suffering change the death penalty system? Might jurors be less likely to sentence a person to death if this antinomy did not exist? Would the death penalty survive a victim-free sentencing phase? 
More than half a century ago, Arendt (1963) famously argued that the very public inclusion of victims in the Eichmann trial degraded the legal process. As this article has sought to demonstrate, the insertion of victim impact testimony into death penalty trials is similarly problematic in the contemporary American context.

\section{REFERENCES}

Acker, James, and David R. Karp, eds. 2006. Wounds that Do Not Bind: Victim-Based Perspectives on the Death Penalty. Durham, NC: Carolina Academic Press.

Acker, James, and Jeanna Marie Mastrocinque. 2006. Causing Death and Sustaining Life: The Law, Capital Punishment, and Criminal Homicide Victims' Survivors. In Wounds that Do Not Bind, ed. James Acker and David R. Karp, 141-60. Durham, NC: Carolina Academic Press.

Alexander, Jeffrey. 2006. Cultural Pragmatics: Social Performance between Ritual and Strategy. In Social Performance: Symbolic Action, Cultural Pragmatics, and Ritual, ed. Jeffrey Alexander, Bernhard Giesen, and Jason Mast, 29-90. Cambridge: Cambridge University Press.

Allen, Howard, and Jerome Clubb. 2008. Race, Class, and the Death Penalty: Capital Punishment in American History. Albany: State University of New York Press.

Arendt, Hannah. 1963. Eichmann in Jerusalem. New York: Penguin.

Arrigo, Bruce, and Christopher Williams. 2003. Victim Vices, Victim Voices, and Impact Statements: On the Place of Emotion and the Role of Restorative Justice in Capital Sentencing. Crime and Delinquency 49:603-26.

Austin, J. L. 1975. How to Do Things with Words, 2nd ed. Cambridge, MA: Harvard University Press.

Baldus, David, Charles Pulaski, and George Woodworth. 1990. Equal Justice and the Death Penalty. Boston, MA: Northeastern University Press.

Baldus, David, and George Woodworth. 2003. Race Discrimination in the Administration of the Death Penalty: An Overview of the Empirical Evidence with Special Emphasis on Post-1990 Research. Criminal Law Bulletin 39:194-226.

Bandes, Susan. 1996. Empathy, Narrative, and Victim Impact Statements. University of Chicago Law Review 63:361-412.

1999, ed. The Passions of Law. New York: New York University Press.

2009. Victims, Closure, and the Sociology of Emotion. Law and Contemporary Problems $72: 1-26$.

Barker, Vanessa. 2007. The Politics of Pain: A Political Institutionalist Analysis of Crime Victims' Moral Protests. Law and Society Review 41:619-64.

Bright, Steven. 1994. Counsel for the Poor: The Death Sentence Not for the Worst Crime but for the Worst Lawyer. Yale Law Journal 103:1835-83.

1995. Discrimination, Death and Denial: The Tolerance of Racial Discrimination in the Infliction of the Death Penalty. Santa Clara Law Review 35:433-83.

Burawoy, Michael. 2000. Introduction: Reaching for the Global. In Global Ethnography: Forces, Connections, and Imaginations in a Postmodern World, ed. Michael Burawoy, Joseph A. Blum, Sheba George, Zsuzsa Gille,and Millie Thayer, 1-40. Berkeley, CA: University of California Press.

Clifford, James, and George Marcus. 1986. Writing Culture: The Poetics and Politics of Ethnography. Berkeley, CA: University of California Press.

Cooley, Craig 2004. Reforming the Forensic Science Community to Avert the Ultimate Injustice. Stanford Law and Policy Review 15:381-87.

— 2005. Mapping the Monster's Mental Health and Social History: Why Capital Defense Attorneys and Public Defender Death Penalty Units Require the Services of Mitigation Specialists. Oklahoma City University Law Review 30:23-41.

Dickson-Swift, Virginia, Erica L. James, Sandra Kippen, and Pranee Liamputtong. 2009. Researching Sensitive Topics: Qualitative Research as Emotion Work. Qualitative Research 9:61-79. 
Durkheim, Émile. [1915] 1965. The Elementary Forms of the Religious Life. New York: The Free Press.

Eisenberg, Theodore, Stephen Garvey, and Martin T. Wells. 2003. Victim Characteristics and Victim Impact Evidence in South Carolina Capital Cases. Cornell Law Review 88:306-43.

Engle, M. 2000. Due Process Limitations on Victim Impact Evidence. Capital Defense Journal 13: $55-83$.

Falzon, Mark-Anthony, ed. 2009. Multi-Sited Ethnography: Theory, Praxis and Locality in Contemporary Research. Aldershot, UK: Ashgate.

Fleury-Steiner, Benjamin. 2004. Jurors' Stories of Death: How America's Death Penalty Invests in Inequality. Ann Arbor, MI: University of Michigan Press.

Galanter, Marc. 2004. The Vanishing Trial: An Examination of Trials and Related Matters in Federal and State Courts. Journal of Empirical Legal Studies 3:459-570.

Garland, David. 2001. The Culture of Control: Crime and Social Order in Contemporary Society. Chicago: University of Chicago Press.

Garvey, Stephen. 2000. The Emotional Economy of Capital Sentencing. New York University Law Review 75:26-73.

Gershowitz, Adam. 2010. Statewide Capital Punishment: The Case for Eliminating Counties' Role in the Death Penalty. Vanderbilt Law Review 63:307-59.

Goffman, Erving. 1959. The Presentation of Self in Everyday Life. New York: Anchor Books.

1961. Asylums: Essays on the Social Situation of Mental Patients and Other Inmates. New York: Doubleday Anchor.

Goodrum, Sarah. 2013. Bridging the Gap Between Prosecutors' Cases and Victims' Biographies in the Criminal Justice System Through Shared Emotions. Law EO Social Inquiry 38:257-87.

Haney, Craig. 2003. Mitigation and the Study of Lives: On the Roots of Violent Criminality and the Nature of Capital Justice. In America's Experiment with Capital Punishment: Reflections on the Past, Present, and Future of the Ultimate Penal Sanction, ed. James Acker, James, Robert Bohm, and Charles Lanier, 7-14. Durham, NC: Carolina Academic Press.

- 2004. Condemning the Other in Death Penalty Trials: Biographical Racism, Structural Mitigation, and the Empathetic Divide. DePaul Law Review 53:1557-90.

2005. Death by Design: Capital Punishment as a Social Psychological System. New York: Oxford University Press.

Hockney, Jenny. 2001. Changing Death Rituals. In Grief, Mourning and Death Ritual ed. Jenny Hockey, Jean Katz, and Neil Small, 185-211. Buckingham, UK: Open University Press.

Hostettler, John. 2006. Fighting for Justice: The History and Origins of Adversary Trial. Winchester, UK: Waterside Press.

- 2009. A History of Criminal Justice in England and Wales. Winchester, UK: Waterside Press.

Hubbard, Gill, Kathryn Backett-Milburn, and Debbie Kemmer. 2001. Working with Emotion: Issues for the Researcher in Fieldwork and Teamwork. International Journal of Social Research Methodology 4:119-37.

Hume, Lynne, and Jane Mulcock, eds. 2004. Anthropologists in the Field: Cases in Participant Observation. New York: Columbia University Press.

Johnson, Sherri Lynn. 2003. Speeding in Reverse: An Anecdotal View of Why Victim Impact Testimony Should Not Be Driving Capital Prosecutions. Cornell Law Review 88:555-68.

Karp, David, and Jarrett Warshaw. 2006. Their Day in Court: The Role of Murder Victims' Families in Capital Juror Decision Making. in Wounds that Do Not Bind: Victim-Based Perspectives on the Death Penalty, ed. James Acker and David R. Karp, 275-95. Durham, NC: Carolina Academic Press.

Karstedt, Susanne. 2002. Emotions and Criminal Justice. Theoretical Criminology 6:299-317.

Langbein, John H. 2003. The Origins of the Adversary Criminal Trial. Oxford: Oxford University Press.

Lofquist, William. 2001. Putting Them There, Keeping Them There, and Killing Them: An Analysis of State-Level Variations in Death Penalty Intensity. Iowa Law Review 87:1505-57.

Logan, Wayne. 1999. Through the Past Darkly: A Survey of the Uses and Abuses of Victim Impact Evidence in Capital Trials. Arizona Law Review 41:143-92. 
2000. Opining on Death: Witness Sentence Recommendations in Capital Trials. Boston College Law Review 41:517-47.

— 2006. Victims, Survivors, and the Decisions to Seek and Impose Death. In Wounds that Do Not Bind: Victim-Based Perspectives on the Death Penalty, ed. James Acker, and David R. Karp, 161-77. Durham, NC: Carolina Academic Press.

Luhrmann, Tanya. 1989. Persuasions of the Witch's Craft: Ritual Magic in Modem Culture. Cambridge, MA: Harvard University Press

Luginbuhl, James, and Michael Burkhead. 1995. Victim Impact Evidence in a Capital Trial: Encouraging Votes for Death. American Journal of Criminal Justice 20:1-16.

Myers, Bryan, and Jack Arbuthnot. 1999. The Effects of Victim Impact Evidence on the Verdicts and Sentencing Judgments of Mock Jurors. Journal of Offender Rehabilitation 29:95-112.

Nadler, Janice, and Mary Rose. 2002. Victim Impact Testimony and the Psychology of Punishment. Cornell Law Review 88:419-56.

Ogletree, Charles. 2002. Black Man's Burden: Race and the Death Penalty in America. Oregon Law Review 81:15-38.

Phillips, A. K. 1997. Thou Shalt Not Kill Any Nice People: The Problem of Victim Impact Statements in Capital Sentencing. American Criminal Law Review 35:93-118.

Pratt, John. 2000. Emotive and Ostentatious Punishment: Its Decline and Resurgence in Modern Society. Punishment and Society 2:417-41.

Redick, William, Bradley MacLean, and Matthew Truett. 2008. Pretend Justice: Defense Representation in Tennessee Death Penalty Cases. University of Memphis Law Review 38:303-463.

Reed, Mark D., and Brenda Sims Blackwell. 2006. Secondary Victimization among Families of Homicide Victims: The Impact of the Justice Process on Co-Victims' Psychological Adjustment and Service Utilization. In Wounds that Do Not Bind: Victim-Based Perspectives on the Death Penalty, ed. James Acker and David R. Karp, 253-73. Durham, NC: Carolina Academic Press.

Rosenblatt, Paul, Patricia Walsh, and Douglas Jackson. 1976. Grief and Mourning in Cross-Cultural Perspective. New York: Human Relations Area Files Press.

Sarat, Austin. 1998. Between (the Presence of) Violence and (the Possibility of) Justice: Lawyering Against Capital Punishment. In Cause Lawyering: Political Commitments and Professional Responsibilities, ed Austin Sarat and Stuart Scheingold, 317-47. New York: Oxford University Press.

2001. When the State Kills: Capital Punishment and the American Condition. Princeton, NJ: Princeton University Press.

Schechner, Richard. 1993. The Future of Ritual: Writings on Culture and Performance. London: Routledge.

Scheper-Hughes, Nancy. 1992. Death without Weeping: The Violence of Everyday Life in Brazil. Berkeley, CA: University of California Press.

Sherman, Lawrence. 2003. Reason for Emotion: Reinventing Justice with Theories, Innovations, and Research-The American Society of Criminology 2002 Presidential Address. Criminology 41:1-37.

Simon, Jonathan. 2007. Governing through Crime: How the War on Crime Transformed American Democracy and Created a Culture of Fear. New York: Oxford University Press.

Smith, Dorothy. 1974. The Conceptual Practices of Power: A Feminist Sociology of Knowledge. Boston, MA: Northeastern University Press.

Strauss, Anselm. 1977. Social Worlds and Their Segmented Processes. In Studies in Symbolic Interaction, ed. Norman Denzin, 23-39. Greenwich, CT: JAI Press.

Sundby, Scott. 2003. The Capital Jury and Empathy: The Problem of Worthy and Unworthy Victims. Cornell Law Review 88:343-81.

Tabak, Ronald J., ed. 1994. The Death of Fairness? Counsel Competency and Due Process in Death Penalty Cases. Houston Law Review 31:1105-20.

Ulysse, Gina. 2007. Downtown Ladies: Informal Commercial Importers, a Haitian Anthropologist and Self-Making in Jamaica. Chicago: University of Chicago Press. 


\section{LAW \& SOCIAL INQUIRY}

Vick, Douglas W. 1995. Poorhouse Justice: Underfunded Indigent Defense Services and Arbitrary Death Sentences. Buffalo Law Review 43:329-460.

Weed, Frank. 1995. Certainty of Justice: Reform in the Crime Victim Movement. New York: Aldine de Gruyter.

White, Welsh. 2006. Litigating in the Shadow of Death: Defense Attorneys in Capital Cases. Ann Arbor, MI: University of Michigan Press.

Williams, Marian, Stephen Demuth, and Jefferson Holcomb. 2007. Understanding the Influence of Victim Gender in Death Penalty Cases: The Importance of Victim Race, Sex, SexRelated Victimization and Jury Decision Marking. Criminology 45:865-91.

\section{CASES CITED}

Booth v. Maryland, 482 U.S. 496 (1987).

Hurst v. Florida, 577 U.S. _ (2016).

Payne v. Tennessee, 501 U.S. 808 (1991).

South Carolina v. Gathers, 490 U.S. 805 (1989).

Woodson v. North Carolina, 428 U.S. 303 (1976). 